Journal of Applied Pharmaceutical Science Vol. 5 (08), pp. 152-158, August, 2015

Available online at http://www.japsonline.com

DOI: 10.7324/JAPS.2015.50824

ISSN 2231-3354 (cc) BY-NC-SA

\title{
Efficacy of Basella alba and Tribulus terrestris extracts for production of monosex Nile tilapia, Oreochromis niloticus
}

\author{
Indranath Ghosal ${ }^{1}$, Debosree Mukherjee ${ }^{1}$, Csaba Hancz ${ }^{2}$, Suman Bhusan Chakraborty ${ }^{1 *}$ \\ ${ }^{1}$ Fish Endocrinology Research Unit, Department of Zoology, University of Calcutta, Kolkata. \\ ${ }^{2}$ Faculty of Agricultural and Environmental Sciences, Kaposvár University, Kaposvár, Hungary.
}

\begin{tabular}{|c|c|}
\hline ARTICLE INFO & ABSTRACT \\
\hline $\begin{array}{l}\text { Article history: } \\
\text { Received on: } 23 / 02 / 2015 \\
\text { Revised on: } 11 / 03 / 2015 \\
\text { Accepted on: } 06 / 05 / 2015 \\
\text { Available online: } 28 / 08 / 2015\end{array}$ & $\begin{array}{l}\text { The present study was aimed to evaluate the efficacy of Basella alba and Tribulus terrestris for induction of } \\
\text { masculinisation in Nile tilpia. B. alba leaves and T. terrestris seeds were extracted with water, ethanol, methanol, } \\
\text { dichloromethane, hexane and successive methanol and mixed sex juveniles of Nile tilapia were subjected to } \\
\text { dietary treatment with the extracts at the concentration of } 0.5,1.0 \text { and } 1.5 \mathrm{gm} / \mathrm{kg} \text { feed. Treatment with both the } \\
\text { plants showed no adverse effect on general fish health. There was no significant interaction effects }(\mathrm{P}>0.05) \text { of }\end{array}$ \\
\hline $\begin{array}{l}\text { Key words: } \\
\text { Basella alba, Tribulus } \\
\text { terrestris, Sex reversal, Nile } \\
\text { tilapia, Ethanol extract }\end{array}$ & $\begin{array}{l}\text { effect }(\mathrm{P}<0.05) \text { of concentration and plant material was observed for percentage of males. Also, there was } \\
\text { significant interaction effect }(\mathrm{P}<0.05) \text { of solvent, concentration and plant material for percentage of males. For } \\
\text { dietary administration of } B \text {. alba leaves, the highest percentage of males }(83.2 \pm 0.7) \text { was obtained by treatment } \\
\text { with ethanol extract at the concentration of } 1.0 \mathrm{gm} / \mathrm{kg} \text { feed. For all the solvents, the highest percentage of males } \\
\text { was observed at the concentration of } 1.0 \mathrm{gm} / \mathrm{kg} \text {. But, in treatment with } T \text {. terrestris seeds, the highest percentage } \\
\text { of males }(88.9 \pm 1.1) \text { was obtained with ethanol extract at the concentration of } 1.5 \mathrm{gm} / \mathrm{kg} \text { feed, which was also the } \\
\text { highest percentage of males for all the treatment categories. }\end{array}$ \\
\hline
\end{tabular}

\section{INTRODUCTION}

The Nile tilapia, Oreochromis niloticus (Linnaeus) is a well-studied, fast-growing and widely cultured fish species. It is currently ranked second only to carps in global production and is likely to be the most important cultured fish in the $21^{\text {st }}$ century (Ridha, 2006). Rapid growth, high tolerance to low water quality, efficient food conversion, resistance to disease, ease of spawning and good consumer acceptance make tilapia a suitable fish for culture (El-Saidy and Gaber, 2005). Females of tilapine species have a high fecundity, generally reproducing at a small size and exhibiting stunted somatic growth at higher densities, while male tilapias exhibit faster growth rates and are often the preferred gender for monosex aquaculture (Hines and Watts, 1995). Synthetic steroids are commonly used to induce sex reversal in tilapia but because of the potential hazards of such steroids; the use of new chemicals is a potential alternative to be explored (Papoulias et al., 2000). Plant extracts containing diverse

\footnotetext{
* Corresponding Author

Suman Bhusan Chakraborty, Department of Zoology, University of

Calcutta.Email:sumanbc76@gmail.com
}

bioactive principles such as alkaloids, flavonoids, pigments, phenolics, terpenoids, steroids and essential oils have been reported to promote various activities like antistress, growth promotion, appetite stimulation, tonic and immunostimulation, and antimicrobial properties in fish culture (Citarasu, 2010; Chakraborty et al., 2011). Phytochemicals are also reported to block biosynthesis as well as action of estrogen by acting as aromatase inhibitors and antagonists to nuclear estrogen receptor in gonad germ cells (Rempel et al., 2008) and hence may be considered as potential mean for inducing sex reversal in fish. However, there are significant variations regarding the efficacy of different phytochemicals for production of all-male fish population and the potential anabolizing and virilizing effects of such plant extracts needs to be clearly documented. Aqueous and methanol extracts from the dry leaves of Basella alba, a fast growing vegetable, probably originating from India (Bamidele et al., 2010), has been reported to possess active components that increase testosterone production in adult male rat testes during in vitro studies (Moundipa et al., 1999; Moundipa et al., 2005). This edible plant has also been described to possess nutritional values including androgenecity in traditional medicines of several countries (Siriwatanametanon et al., 2010). 
However, no studies have been reported related to its in vivo effect on sex reversal, growth and immunostimulation of fish. The herb, Tribulus terrestris has been reported to raise testosterone levels (Bucci, 2000) and to induce sex reversal in fish while administered through immersion technique (Çek et al., 2007a; Çek et al., 2007b). T. terrestris has been observed to be effective for production of monosex Poecilia latipinna population (Kavitha and Subramanian, 2011). The plant extract has also been found to stimulate growth in fish (Çek et al., 2007a, Çek et al., 2007b). Both $B$. alba and T. terrestris have been reported to possess medicinal values (Ignacimuthu et al., 2008). But, use of these plant extracts for sex reversal and growth induction in tilapia during its culture under Indian perspective is not documented. The type and amount of phytoconstituents in the plant extracts may vary with different solvents used for extraction, thereby showing variable results with respect to induction of masculinity (Tiwari et al., 2011). Considering these aspects, the objective of the present study was to investigate the potential effect of these two plants on the masculinisation of $O$. niloticus, to find the most potent solvent for extraction of the phytochemicals from the two plants that would yield the highest androgenic action and to determine an ideal treatment regime for each plants that might produce maximum percentage of males in tilapia.

\section{METHODOLOGY}

\section{Collection of fish seed}

Just hatched juveniles of mixed-sex Nile tilapia Oreochromis niloticus (Linnaeus) was collected from the Fish Hatchery of West Bengal Government, oxygen packed and transported to the laboratory.

\section{Plant extracts preparation}

B. alba leaves and T. terrestris seeds were procured from the local plant market, washed in sterile distilled water, air-dried in shade and powdered. These powdered plant materials (250 gm) were extracted with $500 \mathrm{ml}$ solvents such as water, methanol, ethanol, dichloromethane and hexane in a Soxhlet apparatus and the extracts were evaporated to dryness under pressure at $45^{\circ} \mathrm{C}$ using a rotary evaporator and stored under nitrogen at $-20{ }^{\circ} \mathrm{C}$ in amber glass bottle until those were used (Hussain et al. 2009). For successive extraction with solvents, plant powders (200 gm) were subjected to extraction by maceration under gentle agitation in a glass vessel for $48 \mathrm{~h}$ at room temperature using successively hexane (200 $\mathrm{ml}$ for $5 \mathrm{~h}$, three times), dichloromethane (200 $\mathrm{ml}$ for $5 \mathrm{~h}$, three times) and methanol (200 $\mathrm{ml}$ for $5 \mathrm{~h}$, three times) (Moundipa et al., 2005). The methanol extract was evaporated to dryness under pressure at $45^{\circ} \mathrm{C}$ using a rotary evaporator and stored under nitrogen at $-20{ }^{\circ} \mathrm{C}$ in amber glass bottle until it was used.

\section{Determination of plant extract yield}

The yield of evaporated dried extract based on dry weight basis was calculated from the following equation:

$$
\text { Yield }(\%)=\left(\mathrm{W}_{1} \times 100\right) / \mathrm{W}_{2}
$$

where $\mathrm{W}_{1}$ was the weight of extract after evaporation of the solvent and $\mathrm{W}_{2}$ was the dry weight of the fresh plant sample.

\section{Dietary treatment with different solvent extracts of the plants}

This experiment had $2 \times 6 \times 3$ factorial design: the first factor was plant materials (B. alba leaves and T. terrestris seeds), the second factor was related to solvents used for extraction (aqueous, methanol, ethanol, dichloromethane, hexane and successive methanol), the third factor was related to concentrations of extracts used for dietary treatment $(0.5,1.0$ and $1.5 \mathrm{gm} / \mathrm{kg}$ feed). Three days old mixed sex juveniles of Nile tilapia (mean weight $0.025 \pm 0.009 \mathrm{gm}$; mean length $1.25 \pm 0.012 \mathrm{~cm}$ ) were randomly assigned in glass aquaria (40 fish / aquaria) and three aquaria were assigned for each treatment category. Plant extracts at desired concentrations were dissolved in dimethyl sulfoxide (DMSO) and added to finely ground $(<500-1000 \mu \mathrm{m})$ artificial diet containing $30 \%$ crude protein (Tokyu, Japan) (Moundipa et al. 2005). The feed was then wetted with deionized water, mixed thoroughly, formed into pellets with a pelleter (diameter $2 \mathrm{~mm}$ ), and dried at room temperature. Pelleted feed was pulverized before feeding to the juvenile fish.

\section{Sexing of fish}

Sexing of the juvenile fish was done by the standard acetocarmine squash technique of gonads (Guerrero and Shelton, 1974). Histological studies of the gonads were also performed.

\section{Statistical analysis}

Data were analyzed by IBM SPSS Statistics Version 20 software. Normality of variables was checked before conducting T-probe or ANOVA in GLM where solvent and concentration were considered as fixed and plant as random factors. Treatment means were compared by Tukey's HSD test for fixed factors. For variables not normally distributed nonparametric median tests were applied to evaluate treatment effects.

\section{Qualitative phytochemical studies}

Qualitative phytochemical analysis of the extracts of $T$. terrestris seed and B. alba leaves were carried out using standard procedures (Malpani et al., 2011; Kumar and Bhardwaj, 2012; Ray et al., 2013).

\section{RESULTS AND DISCUSSION}

For both plants, the maximum yield of evaporated dried extracts based on dry weight basis was obtained with water as extracting solvent (Figure 1). The yield for aqueous extract of $B$. alba leaves was $28.35 \%$ while that for $T$. terrestris seeds was 13.4 $\%$. Interestingly, yield for $B$. alba leaves with more polar solvents such as water, methanol and ethanol were comparatively higher than those for $T$. terrestris seeds, but with solvents such as dichloromethane and hexane, the yield percentage is higher for $T$. terrestris seeds (Figure 1). Moreover, the yield percentage with 
successive methanol was found to be higher for $T$. terrestris seeds (4.3\%) compared to that for B. alba leaves $(3.47 \%)$. However, the yield percentage decreased with decreased polarity of the solvents for both the plants (Figure 1). In order to eliminate the influence of the moisture content of the plant, the yield of the extracts from $B$. alba leaves and $T$. terrestris seeds with different solvents were calculated depending on a dry weight basis and the yields were found to be high. Similar high yield from $B$. alba leaves has been reported with methanol in successive extraction with petroleum ether, ethyl acetate and methanol (Siriwatanametanon et al., 2010). Maximum yield percentage for $\mathrm{T}$. terrestris seeds was obtained with aqueous extraction in a study using solvents such as petroleum ether, chloroform, acetone, alcohol and water (Asadulla 2011).

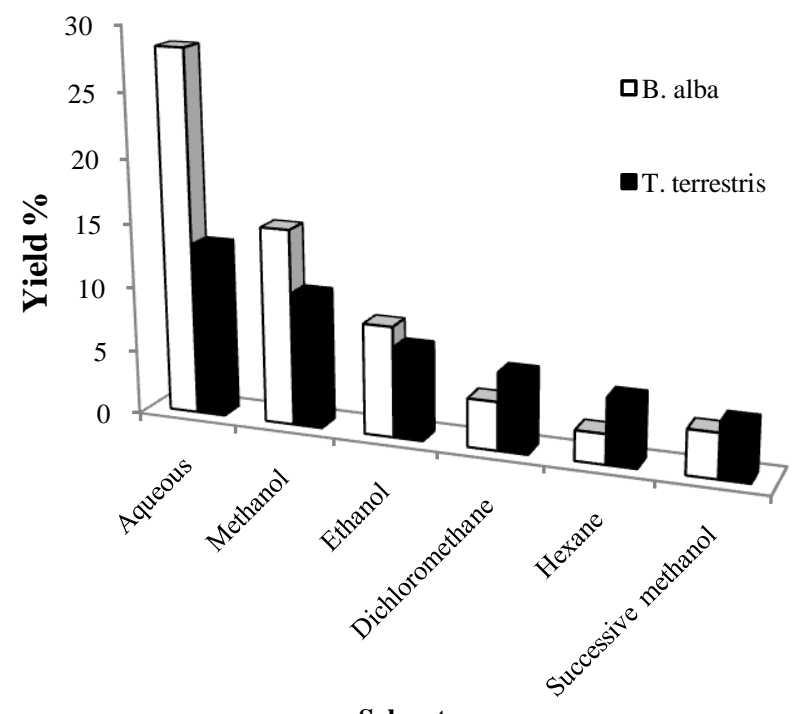

Solvent

Fig. 1: Yield percentage of evaporated dried extracts based on dry weight basis with different solvents for $B$. alba leaves and T. terrestris seeds.

During treatment with different solvent extracts of $B$. alba leaves and $T$. terrestrsis seeds, the survival percentage was $94.96 \pm 0.6$. This high survival indicates that the treatment with both plant extracts has no adverse effects on the general health of the fish. In these groups, the percentage of males was $70.6 \pm 0.8$, females $22.9 \pm 0.7 \%$, while $6.5 \pm 0.5 \%$ of the treated fish was found to be intersex. However, the variables except the percentage of males in different treatment categories are not normally distributed and could not be transformed to achieve normal distribution. Effects of plant materials (B. alba leaves and T. terrestris seeds), solvents used for extraction (aqueous, methanol, ethanol, dichloromethane, hexane and successive methanol), and concentrations of extracts used for dietary treatment $(0.5,1.0$ and $1.5 \mathrm{gm} / \mathrm{kg}$ feed) on percentage of males in tilapia are given in Table 1 . The percentage of males was the lowest in hexane and dichloromethane extraction, aqueous extract showed significantly higher $(\mathrm{P}<0.05)$ percentage of males compared to that in those two groups, but significantly lower $(\mathrm{P}<0.05)$ percentage of males than that in ethanol, methanol and successive methanol categories
(Table 1). Extraction with ethanol showed the highest percentage of males (74.4 \pm 2.8$)$ among the solvents.

Percentage of males was significantly different $(\mathrm{P}<0.05)$ for all concentration categories (Table 1). The highest percentage $(75.0 \pm 0.8)$ of males was observed in $1.0 \mathrm{gm} / \mathrm{kg}$ feed concentration category, while the lowest percentage of males $(66.1 \pm 1.0)$ was observed in $0.5 \mathrm{gm} / \mathrm{kg}$ feed group (Table 1). Plant material showed no significant effect $(\mathrm{P}>0.05)$ on percentage of males. However, treatment with $T$. terrestris seeds yielded higher percentage of males than B. alba leaves (Table 1).

Table 1: Factorial ANOVA comparing percentage of males in tilapia between treatments with extraction with different solvents (aqueous, methanol, ethanol, dichloromethane. Hexane and successive methanol), concentrations $(0.5,1.0$, $1.5 \mathrm{gm} / \mathrm{kg}$ ) and plant materials ( $B$. alba leaves and $T$. terrestris seeds). Notations $\mathrm{a}, \mathrm{b}$ and $\mathrm{c}$ are to compare between the means of solvent extraction category, notations $\mathrm{x}, \mathrm{y}$ and $\mathrm{z}$ are to compare between the means of concentration and notation $\mathrm{p}$ is to compare between the means of plant materials. Values with different superscripts are significantly different $(\mathrm{P}<0.05)$. NS: Not significant. S: Significant.

\begin{tabular}{lll} 
& & Male $(\%)$ \\
\hline & Aqueous & $70.2 \pm 1.5^{\mathrm{b}}$ \\
& Methanol & $72.2 \pm 1.6^{\mathrm{bc}}$ \\
& Ethanol & $74.4 \pm 2.8^{\mathrm{c}}$ \\
& Dichloromethane & $66.8 \pm 1.8^{\mathrm{a}}$ \\
& Hexane & $66.5 \pm 2.2^{\mathrm{a}}$ \\
& Successive methanol & $73.3 \pm 1.6^{\mathrm{c}}$ \\
\hline & 0.5 & $66.1 \pm 1.0^{\mathrm{x}}$ \\
Concentration $(\mathrm{gm} / \mathrm{kg})(\mathrm{C})$ & 1.0 & $75.0 \pm 0.8^{\mathrm{y}}$ \\
& 1.5 & $70.7 \pm 1.9^{\mathrm{z}}$ \\
\hline Plant material $(\mathrm{P})$ & Basella alba leaves & $68.3 \pm 1.1^{\mathrm{p}}$ \\
\hline S X C & Tribulus terrestris seeds & $72.8 \pm 1.2^{\mathrm{p}}$ \\
S X P & & $\mathrm{NS}$ \\
C X P & & $\mathrm{NS}$ \\
S X C X P & & $\mathrm{S}$ \\
\hline
\end{tabular}

There was no significant interaction effects $(\mathrm{P}>0.05)$ of solvent and concentration, and solvent and plant material for percentage of males (Table 1). But, significant interaction effect $(\mathrm{P}<0.05)$ of concentration and plant material was observed for percentage of males (Table 1, Figure 2).

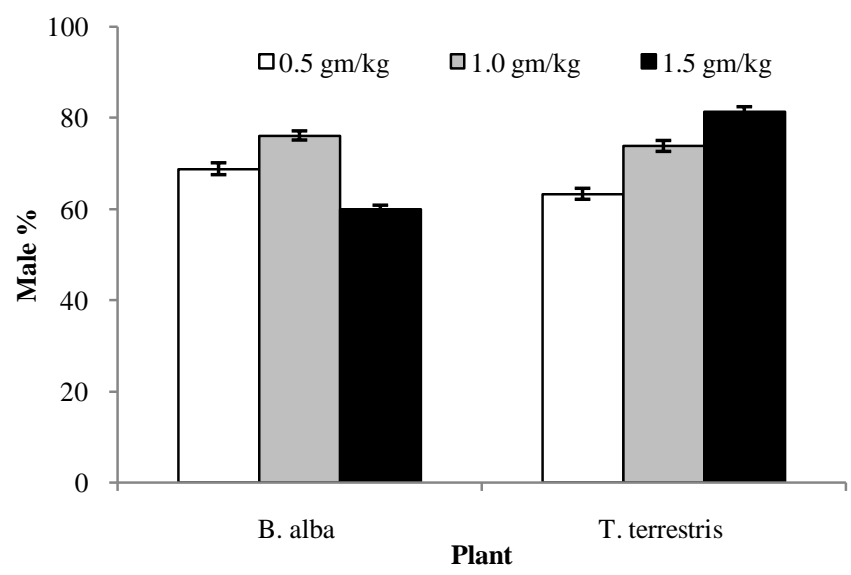

Fig. 2: Percentage of males in tilapia fed diets containing different concentrations of $B$. alba leaves and T. terrestris seeds extracts. Different alphabets above column indicates significant difference $(\mathrm{P}<0.05)$ in means. 
In treatment with $B$. alba leaves, the percentage of males for every concentration differed significantly $(\mathrm{P}<0.05)$ from each other, and the highest percentage of males $(76.1 \pm 1.0)$ was observed at the concentration of $1.0 \mathrm{gm} / \mathrm{kg}$ feed (Figure 2). Similar significant difference $(\mathrm{P}<0.05)$ in male percentage for every concentration was also observed in treatment with $T$. terrestris seeds, but the highest percentage of males $(81.3 \pm 1.1)$ was found at the concentration of $1.5 \mathrm{gm} / \mathrm{kg}$ feed (Figure 2). There was significant interaction effect $(\mathrm{P}<0.05)$ of solvent, concentration and plant material for percentage of males (Tables 1,2). For dietary administration of $B$. alba leaves, the highest percentage of males $(83.2 \pm 0.7)$ was obtained for treatment with ethanol extract at the concentration of $1.0 \mathrm{gm} / \mathrm{kg}$ feed followed by treatment with successive methanol extract at the same concentration (Table 2). For all the solvents, the highest percentage of males was observed at the concentration of $1.0 \mathrm{gm} / \mathrm{kg}$ (Table 2). But, in treatment with $T$. terrestris seeds, the highest percentage of males $(88.9 \pm 1.1)$ was obtained with ethanol extract at the concentration of $1.5 \mathrm{gm} / \mathrm{kg}$ feed, which was also the highest percentage of males for all the treatment categories (Table 2). For $T$. terrestris treatment with all the solvents, the highest percentage of male was observed at the concentration of $1.5 \mathrm{gm} / \mathrm{kg}$ feed (Table 2).

Table 2: Percentage of males in tilapia fed diets containing extraction of $B$. alba leaves and T. terrestris seeds with different solvents and at different concentrations. Different superscripts mark significant difference $(\mathrm{P}<0.05)$ in means within columns.

\begin{tabular}{|c|c|c|c|}
\hline Plant material & Solvent & Concentration & Male \% \\
\hline \multirow[t]{18}{*}{ B. alba leaves } & Aqueous & $0.5 \mathrm{gm} / \mathrm{kg}$ & $65.4 \pm 0.7^{\text {cdetg }}$ \\
\hline & & $1.0 \mathrm{gm} / \mathrm{kg}$ & $72.9 \pm 0.8^{\text {ghıklmn }}$ \\
\hline & & $1.5 \mathrm{gm} / \mathrm{kg}$ & $62.1 \pm 1.1^{\text {abcde }}$ \\
\hline & Methanol & $0.5 \mathrm{gm} / \mathrm{kg}$ & $73.7 \pm 1.9^{\mathrm{ijklmno}}$ \\
\hline & & $1.0 \mathrm{gm} / \mathrm{kg}$ & $74.7 \pm 1.0^{\mathrm{klmno}}$ \\
\hline & & $1.5 \mathrm{gm} / \mathrm{kg}$ & $63.3 \pm 1.7^{\text {bcdet }}$ \\
\hline & Ethanol & $0.5 \mathrm{gm} / \mathrm{kg}$ & $74.2 \pm 1.4^{\mathrm{jklmno}}$ \\
\hline & & $1.0 \mathrm{gm} / \mathrm{kg}$ & $83.2 \pm 0.7^{\mathrm{pq}}$ \\
\hline & & $1.5 \mathrm{gm} / \mathrm{kg}$ & $54.9 \pm 1.0^{\mathrm{a}}$ \\
\hline & Dichloromethane & $0.5 \mathrm{gm} / \mathrm{kg}$ & $65.5 \pm 0.9^{\text {cdetgh }}$ \\
\hline & & $1.0 \mathrm{gm} / \mathrm{kg}$ & $71.3 \pm 1.6^{\text {tghijklm }}$ \\
\hline & & $1.5 \mathrm{gm} / \mathrm{kg}$ & $58.4 \pm 0.9^{\text {abcd }}$ \\
\hline & Hexane & $0.5 \mathrm{gm} / \mathrm{kg}$ & $60.7 \pm 0.4^{\text {abcde }}$ \\
\hline & & $1.0 \mathrm{gm} / \mathrm{kg}$ & $76.2 \pm 1.0^{\mathrm{Imnop}}$ \\
\hline & & $1.5 \mathrm{gm} / \mathrm{kg}$ & $58.3 \pm 1.0^{\mathrm{abcd}}$ \\
\hline & Successive methanol & $0.5 \mathrm{gm} / \mathrm{kg}$ & $73.5 \pm 0.8^{\text {hıjklmno }}$ \\
\hline & & $1.0 \mathrm{gm} / \mathrm{kg}$ & $78.2 \pm 0.3^{\mathrm{Imnop}}$ \\
\hline & & $1.5 \mathrm{gm} / \mathrm{kg}$ & $63.3 \pm 0.4^{\text {bcdef }}$ \\
\hline \multirow{18}{*}{$\begin{array}{l}\text { T.terrestris } \\
\text { seeds }\end{array}$} & Aqueous & $0.5 \mathrm{gm} / \mathrm{kg}$ & $67.2 \pm 1.5^{\text {efghijk }}$ \\
\hline & & $1.0 \mathrm{gm} / \mathrm{kg}$ & $73.0 \pm 1.5^{\text {ghijklmno }}$ \\
\hline & & $1.5 \mathrm{gm} / \mathrm{kg}$ & $80.8 \pm 0.8^{\text {nop }}$ \\
\hline & Methanol & $0.5 \mathrm{gm} / \mathrm{kg}$ & $66.2 \pm 1.9^{\operatorname{detghij}}$ \\
\hline & & $1.0 \mathrm{gm} / \mathrm{kg}$ & $74.2 \pm 3.0^{\mathrm{jkImno}}$ \\
\hline & & $1.5 \mathrm{gm} / \mathrm{kg}$ & $81.0 \pm 3.0^{\text {opq }}$ \\
\hline & Ethanol & $0.5 \mathrm{gm} / \mathrm{kg}$ & $65.7 \pm 0.5^{\text {cdetghi }}$ \\
\hline & & $1.0 \mathrm{gm} / \mathrm{kg}$ & $79.5 \pm 0.3^{\text {nop }}$ \\
\hline & & $1.5 \mathrm{gm} / \mathrm{kg}$ & $88.9 \pm 1.1^{q}$ \\
\hline & Dichloromethane & $0.5 \mathrm{gm} / \mathrm{kg}$ & $57.8 \pm 1.5^{\mathrm{abc}}$ \\
\hline & & $1.0 \mathrm{gm} / \mathrm{kg}$ & $70.2 \pm 0.4^{\text {tghıjkl }}$ \\
\hline & & $1.5 \mathrm{gm} / \mathrm{kg}$ & $77.4 \pm 1.4^{\mathrm{Imnop}}$ \\
\hline & Hexane & $0.5 \mathrm{gm} / \mathrm{kg}$ & $56.0 \pm 1.9^{\mathrm{ab}}$ \\
\hline & & $1.0 \mathrm{gm} / \mathrm{kg}$ & $67.7 \pm 1.5^{\text {efghijk }}$ \\
\hline & & $1.5 \mathrm{gm} / \mathrm{kg}$ & $79.9 \pm 0.1^{\text {nop }}$ \\
\hline & Successive methanol & $0.5 \mathrm{gm} / \mathrm{kg}$ & $66.7 \pm 1.7^{\text {etghı } \mathrm{k}}$ \\
\hline & & $1.0 \mathrm{gm} / \mathrm{kg}$ & $78.3 \pm 1.7^{\mathrm{mnop}}$ \\
\hline & & $1.5 \mathrm{gm} / \mathrm{kg}$ & $79.8 \pm 2.7^{\text {nop }}$ \\
\hline
\end{tabular}

Results of non-parametric tests for percentage of survival, females and intersex, which showed no normal distribution, indicated that only the medians of female percentage differed significantly $(\mathrm{P}<0.05)$ across categories of plant, solvent and concentration (Table 3). Qualitative analysis for phytochemicals revealed the presence of alkaloids and steroids in all the solvent extracts for both $B$. alba leaves and $T$. terrestris seeds (Table 4). Tannins and saponins were present in aqueous, ethanol and methanol extracts for both the plants, and in hexane extract of B. alba. Flavonoids were present in all solvent extracts except aqueous for both the plants, while glycosides were not found in any extracts. Carbohydrates were found in ethanol and methanol extracts of $B$. alba leaves and only in methanol extract for $T$. terrestris seeds (Table 4). The result indicates that treatment with different solvent extracts of both $B$. alba leaves and $T$. terrestris seeds has no adverse effects on general fish health. Similar results were obtained in other studies with Poecilia reticulata and $P$. latipinna as well where immersion treatment with T. terrestris extract showed no significant difference in survival of fish compared to that of untreated control (Çek et al., 2007b; Kavitha \& Subramanian, 2011). Immersion treatment with B. alba leaf aqueous extract resulted in no significant difference in survival of tilapia (Ghosal and Chakraborty 2014). B. alba has been reported to be used in traditional medicine to treat sexual asthenia and infertility in man (Adhikari et al., 2012). The methanol extract of its leaves was found to stimulate testosterone production in testicular fractions and Leydig cell cultures, and in normal adult albino male rats (Moundipa et al., 2005; Nantia et al., 2011). Similar increase in serum testosterone level was also reported in male rats treated with aqueous extract of $B$. alba through gastric intubation (Moundipa et al., 1999). Dietary treatment with methanol extract of $B$. alba was reported to cause significant increase in percentage of males in guppy, Poecilia reticulata (Chakraborty et al., 2012). Interestingly, during treatment with $B$. alba leaf extracts for all the solvents, the highest treatment concentration of $1.5 \mathrm{gm} / \mathrm{kg}$ produced the lowest percentage of males among the different treatment categories in the present study (Table 2). Reduced masculinisation and paradoxical feminization has been observed in fish treated with high concentration of synthetic steroids as well (Beardmore et al., 2001; Devlin and Nagahama, 2002). Dietary inclusion of commercially available $T$. terrestris extract at a concentration of $2.5 \mathrm{gm} / \mathrm{kg}$ basal diet have resulted in $84 \%$ male population in $O$. niloticus (Omitoyin et al., 2013).

In another experiment, $97 \%$ masculinisation was achieved in P. latipinna by immersing 0-day-old fry for 60 days in water containing $50 \mathrm{ppm} T$. terrestris extracted in $70 \%$ ethanol (Kavitha and Subramanian, 2011). Results emanating from this study indicate a dose dependent masculinisation effect of $T$. terrestris extracts on Nile tilapia, which corroborates with other studies, where percentage of males increased with increase in the $T$. terrestris concentration in $P$. latipinna, $P$. reticulata, Cichlasoma nigrofasciatum and Clarias gariepinus (Kavitha and Subramanian, 2011; Kavitha et al., 2012; Çek et al., 2007b; Çek et 
Table. 3: Non-parametric tests for survival percentage, female percentage and intersex percentage for plants, solvents and concentrations. Asymptotic significances are displayed. The significance level is 0.05 .

\begin{tabular}{|c|c|c|c|}
\hline \multicolumn{4}{|c|}{ Hypothesis Test Summary } \\
\hline Null Hypothesis & Test & Significance & Decision \\
\hline The medians of survival percentage are the same across categories of plant & Independent Samples Median Test & 0.120 & Retain the null hypothesis \\
\hline The medians of female percentage are the same across categories of plant & Independent Samples Median Test & 0.034 & Reject the null hypothesis \\
\hline The medians of intersex percentage are the same across categories of plant & Independent Samples Median Test & 0.178 & Retain the null hypothesis \\
\hline The medians of survival percentage are the same across categories of solvent & Independent Samples Median Test & 0.850 & Retain the null hypothesis \\
\hline The medians of female percentage are the same across categories of solvent & Independent Samples Median Test & 0.029 & Reject the null hypothesis \\
\hline The medians of intersex percentage are the same across categories of solvent & Independent Samples Median Test & 0.615 & Retain the null hypothesis \\
\hline The medians of survival percentage are the same across categories of concentration & Independent Samples Median Test & 0.860 & Retain the null hypothesis \\
\hline The medians of female percentage are the same across categories of concentration & Independent Samples Median Test & 0.001 & Reject the null hypothesis \\
\hline The medians of intersex percentage are the same across categories of concentration & Independent Samples Median Test & 0.641 & Retain the null hypothesis \\
\hline
\end{tabular}

Table. 4: Qualitative analysis of phytochemicals in different solvent extracts of B. alba leaves and T. terrestris seed

\begin{tabular}{|c|c|c|c|c|c|c|c|c|}
\hline \multirow[t]{2}{*}{ Plant } & \multirow[t]{2}{*}{$\begin{array}{c}\text { Solvent for } \\
\text { extraction }\end{array}$} & \multicolumn{7}{|c|}{ Phytochemical groups } \\
\hline & & Tannin & Saponin & Alkaloid & Carbohydrate & Glycoside & Flavonoid & Steroid / Terpenoid \\
\hline \multirow[t]{6}{*}{ B. alba leaves } & Aqueous & + & + & + & - & - & - & + \\
\hline & Ethanol & + & + & + & + & - & + & + \\
\hline & Methanol & + & + & + & + & - & + & + \\
\hline & Dichloro methane & - & - & + & - & - & + & + \\
\hline & Hexane & + & - & + & - & - & + & + \\
\hline & Successive methanol & - & - & + & - & - & + & + \\
\hline \multirow[t]{6}{*}{ T. terrestris seeds } & Aqueous & + & + & + & - & - & - & + \\
\hline & Ethanol & + & + & + & - & - & + & + \\
\hline & Methanol & + & + & + & + & - & + & + \\
\hline & Dichloro methane & - & - & + & - & - & + & + \\
\hline & Hexane & - & - & + & - & - & + & + \\
\hline & Successive methanol & - & - & + & - & - & + & + \\
\hline
\end{tabular}

al., 2007a; Turan and Çek, 2007). As the highest treatment concentration of $1.5 \mathrm{gm} / \mathrm{kg}$ feed produced the maximum percentage of males for all solvent extracts of $T$. terrestris seeds (Table 2) however further experiments with increased concentration might be required to achieve $100 \%$ sex reversal with the plant. The plant has been reported to be used in traditional medicine to treat sexual asthenia and infertility in man (Adaikan et al., 2001). Oral treatment with $T$. terrestris extract was found to significantly increase body weight, intracavernous pressure, mount and intromission frequencies while to decrease mount latency and postejaculatory interval in Sprague-Dawley rat (Gauthaman et al., 2003). T. terrestris extract was reported to contain steroid saponin protodioscin and found to increase concentration of some of the sex hormones in rat (Gauthaman et al., 2002; Gauthaman and Ganesan, 2008). However, Neychev and Mitev (2005) observed that the steroid saponins in $T$. terrestris possess neither direct nor indirect androgen-increasing properties in young men. Successful determination of biologically active compounds from plant material is largely dependent on the type of solvent used in the extraction procedure (Ugochukwu et al., 2013, Pandey and Tripathi 2014). Although the present work has indicated that treatment with extracts of different solvents of both the plants might induce high rate of masculinisation, whether this potency is caused by increase in androgen level cannot be deduced as the serum testosterone level was not measured during the study. Qualitative analysis for phytochemicals revealed the presence of steroids in all the extracts of $B$. alba leaves and $T$. terrestris seeds, which might render the androgenic activity of the extracts. A variety of pathways have been postulated to be associated with functional mechanisms of phyto-compounds causing both masculinisation and feminization at different concentrations (Chakraborty et al., 2014). Further investigations are required to deduce the functional mechanisms behind the androgenic potency of these two plants.

\section{CONCLUSION}

The results emanating from this study indicate that both the plants might be used as an alternative method to produce allmale tilapia population in an environment-friendly manner using a natural product. However, T. terrestris might be regarded to be more potent for induction of masculinization in Nile tilapia as it produced higher percentage of males compared to $B$. alba with all the solvents. Dietary treatment with ethanol extracts of both the plants resulted in production of the highest percentage of males, but the concentrations observed for such production were different. However, the highest percentage of males produced by the plant materials was found to be well below the ideal requirement of $100 \%$ male population. Thus, further studies would be required to establish an ideal treatment regime for production of all-male tilapia population using the plant materials and to provide conclusive evidence regarding their efficacy to be used as a sexreversal agent in tilapia culture.

\section{ACKNOWLEDGEMENT}

The research is financed by the University Grants Commission (Major Research Project, F. No. 42-519/2013(SR)). The Vice Chancellor, University of Calcutta is also acknowledged for giving permission for conducting the research work. 


\section{REFERENCES}

Adaikan PG, Gauthaman K, and Prasad RNV. History of herbal medicines with an insight on the pharmacological properties of Tribulus terrestris. The Aging Male, 2001; 4(3): 163-169.

Adhikari R, Naveen HNK, and Shruthi SD. A Review on Medicinal Importance of Basella alba L. International Journal of Pharmaceutical Sciences and Drug Research, 2012; 4: 110-114.

Asadulla S. Anti-arrthritic activities of Tribulus terrestris Linn fruits (Gokhru) in albino rats. International Journal of Research in Pharmacy and Chemistry, 2011; 1(3): 334-337.

Bamidele O, Akinnuga AM, Olorunfemi JO, Odetola OA, Oparaji CK, and Ezeigbo N. Effects of aqueous extract of Basella alba leaves on haematological and biochemical parameters in albino rats. African Journal of Biotechnology. 2010; 9: 6952-6955.

Beardmore JA, Mair GC, and Lewis RI. Monosex male production in finfish as exemplified by tilapia: applications, problems, and prospects. Aquaculture. 2001; 197: 283-301.

Bucci LR. Selected herbals and human exercise performance. The American Journal of Clinical Nutrition. 2000; 72(2): 624S-636S.

Çek S, Turan F, and Atik E. Masculinization of Convict Cichlid (Cichlasoma nigrofasciatum) by immersion in Tribulus terrestris extract. Aquaculture International. 2007a; 15(2): 109-119.

Çek Ş, Turan F, and Atik E. The effects of gokshura, Tribulus terrestris on sex differentiation of guppy, Poecilia reticulata. Pakistan Journal of Biological Sciences. 2007b; 10(5): 718-725.

Chakraborty SB, and Hancz C. Application of phytochemicals as immunostimulant, antipathogenic and antistress agents in finfish culture. Reviews in Aquaculture. 2011; 3: 103-119.

Chakraborty SB, Horn P, and Hancz C. Application of phytochemicals as growth promoters and endocrine modulators in fish culture. Reviews in Aquaculture. 2014; 6: 1-19.

Chakraborty SB, Molnár T, and Hancz C. Effects of methyltestosterone, tamoxifen, genistein and Basella alba extract on masculinization of guppy (Poecilia reticulata). Journal of Applied Pharmaceutical Science. 2012; 2: 048-052.

Citarasu T. Herbal biomedicines: a new opportunity for aquaculture industry. Aquaculture International. 2010; 18: 403-414.

Devlin RH, and Nagahama Y. Sex determination and sex differentiation in fish: an overview of genetic, physiological, and environmental influences. Aquaculture. 2002; 208: 191-364.

El-Saidy DMSD, and Gaber MMA. Effect of dietary protein levels and feeding rates on growth performance, production traits and body composition of Nile tilapia, Oreochromis niloticus (L.) cultured in concrete tanks. Aquaculture Research. 2005; 36(2): 163-171.

Gauthaman K, Adaikan PG, and Prasad RN. Aphrodisiac properties of Tribulus terrestris extract (Protodioscin) in normal and castrated rats. Life Sciences. 2002; 71 (12): 1385-1396.

Gauthaman K, and Ganesan AP. The hormonal effects of Tribulus terrestris and its role in the management of male erectile dysfunction - an evaluation using primates, rabbits and rat. Phytomedicine. 2008; 15: 44-54.

Gauthaman KA, Ganesan P, and Prasad RNV. Sexual effects of puncturevine (Tribulus terrestris) extract (Protodioscin): an evaluation using a rat model. The Journal of Alternative and Complementary Medicine. 2003; 9(2): 257-265.

Ghosal I, and Chakraborty SB. Effects of the Aqueous Leaf Extract Of Basella alba on Sex Reversal of Nile Tilapia, Oreochromis niloticus. IOSR Journal of Pharmacy and Biological Sciences. 2014; 9(2):162-164.

Guerrero RD, and Shelton WL. An aceto-carmine squash method for sexing juvenile fishes. The Progressive Fish- Culturist. 1974; 36(1), 56.
Gurib-Fakim A. Medicinal plants: Traditions of yesterday and drugs of tomorrow. Molecular Aspects of Medicine. 2006; 27: 193.

Hines GA, and Watts SA. Nonsteroidal chemical sex manipulation of tilapia. Journal of World Aquaculture Society. 1995; 26(1): 98-102.

Hussain J, Khan AL, Rehman N, Zainullah, Hussain ST, Khan F and Shinwari ZK. Proximate and nutrient analysis of selected medicinal plant species of Pakistan. Pakistan J.Nut. 2009; 8 (1): 620 624.

Ignacimuthu S, Ayyanar M, and Sankarasivaraman K. Ethnobotanical study of medicinal plants used by Paliyar tribals in Theni district of Tamil Nadu, India. Fitoterapia. 2008; 79: 562-568.

Kavitha P, and Subramanian P. Effect of Tribulus terrestris on monosex production in Poecilia latipinna. Current Science. 2011; 101(1): 100-104.

Kavitha P, Ramesh R, and Subramanian P. Histopathological changes in Poecilia latipinna male gonad due to Tribulus terrestris administration, In Vitro Cellular \& Developmental Biology-Animal. 2012; 48(5): 306-312.

Kumar A, and Bhardwaj A. Comparative, qualitative and quantitative chemotypic characterization among north Indian Tribulus terrestris. International Research Journal of Pharmacy. 2012;3(6):212218.

Malpani MO, Rajput PR, Mane VD, and Dhabe PS. Phytochemical screening, anifungal activity and curative impact on Channa punctatus fish of Butea monosperma (Lam): flower, leaves and gum. Der Pharmacia Lettre. 2011; 3(5): 271-280.

Moundipa PF, Beboy NSE, Zelefack F, Ngoula S, Tsamo E, Schill W-B, and Monsees TK. Effects of Basella alba and Hibiscus macranthus extracts on testosterone production of adult rat and bull Leydig cells. Asian Journal of Andrology. 2005; 7: 411-417.

Moundipa PF, Kamtchouing P, Koueta N, Tantchou J, Foyang NPR, and Mbiapo FT. Effects of aqueous extracts of Hibiscus macranthus and Basella alba in mature rat testis function. Journal of Ethnopharmacology. 1999; 65: 133-139.

Nantia EA, Travert C, Manfo F-PT, Carreau S, Monsees TK, and Moundipa PF. Effects of the Methanol Extract of Basella alba L (Basellaceae) on Steroid Production in Leydig Cells. International Journal of Molecular Sciences. 2011; 12: 376-384.

Neychev VK, and Mitev VI. The aphrodisiac herb Tribulus terrestris does not influence the androgen production in young men. Journal of Ethnopharmacology. 2005; 101(3): 319-323.

Omitoyin BO, Ajani EK, and Sadiq HO. Preliminary investigation of Tribulus terrestris (Linn., 1753) extract as natural sex reversal agent in Oreochromis niloticus (Linn., 1758) larvae. International Journal of Aquaculture. 2013; 3(23): 133-137.

Pandey A, Tripathi S. Concept of standardization, extraction and pre phytochemical screening strategies for herbal drug. Journal of Pharmacognosy and Phytochemistry. 2014; 2(5): 115-119.

Papoulias DM, Noltie DB, and Tillitt DE. Effects of methyltestosterone exposure on sexual differentiation in medaka, Oryzias latipes. Marine Environmental Research. 2000; 50: 181-184.

Ray S., Chatterjee S, and Chakrabarti CS. Antiprolifertive activity of allelochemicals present in aqueous extract of Synedrella nodiflora (L.) Gaertn. in apical meristems and Wistar rat bone marrow cells. IOSR Journal of Pharmacy. 2013; 3(2): 1-10.

Rempel MA, and Schlenk D. Effects of environmental estrogens and antiandrogens on endocrine function, gene regulation, and health in fish. International Review of Cell and Molecular Biology.2008;267:207-252.

Ridha MT. Comparative study of growth performance of three strains of Nile tilapia, Oreochromis niloticus, L. at two stocking densities. Aquaculture Research. 2006; 37(2): 172-179. 
Siriwatanametanon N, Fiebich BL, Efferth T, Prietoa JM, and Heinrich M. Traditionally used Thai medicinal plants: In vitro anti-inflammatory, anticancer and antioxidant activities. Journal of Ethnopharmacology. 2010; 130: 196-207.

Tiwari P, Kumar B, Kaur M, Kaur G, Kaur H. Phytochemical screening and extraction: a review. Internationale Pharmaceutica Sciencia. 2011; 1(1): 98-106.

Turan F, and Çek Ş. Masculinization of African catfish (Clarias gariepinus) treated with gokshura (Tribulus terrestris). Israeli Journal of Aquaculture - Bamidgeh. 2007; 59(4): 224-229.

Ugochukwu SC, Uche IA, Ifeanyi O. Preliminary phytochemical screening of different solvent extracts of stem bark and roots of Dennetia tripetala G. Baker. Asian Journal of Plant Science and Research. 2013; 3(3):10-13.

\section{How to cite this article:}

Indranath Ghosal, Debosree Mukherjee, Csaba Hancz, Suman Bhusan Chakraborty. Efficacy of Basella alba and Tribulus terrestris extracts for production of monosex Nile tilapia, Oreochromis niloticus. J App Pharm Sci, 2015; 5 (08): 152-158. 